\title{
Post-Modernism and THE Three Generations of Museums
}

\section{Esben Kjeldbaek}

Ten years ago visiting museums in Normandy I had an experience that keeps coming back. It was not just that the war museums in Calais and Caen were very different from each other. Rather, each seemed to represent an extreme version of how museums begin and eventually reach a sort of evolutionary peak. This difference comes to mind every time postmodern museum criticism tells me that old museums are keepers of (usually harmful) myth, and that new ones must therefore self-critically deconstruct nationalist beliefs and themselves promote humanitarian values and even repentance in general.

\section{Two War Museums}

The war museum in Calais was housed in a German communications bunker situated near the centre of the city. The bunker was partly over ground, but when you entered your first impression was the musty smell. Everywhere stood hand-painted exhibition cases teeming with objects. Second-hand mannequins wore uniforms and stared back at you with confident grins. I do not remember any stated purpose of the exhibition, but the general subject was the fate of Calais during WW II. This meant for instance also the engine of a German Messerschmitt that had happened to be shot down near the town. At the exit you could buy dud machinegun shells for five francs apiece. Coming from the un-reformed Resistance Museum in Copenhagen, I felt rather at home.
The objects in the exhibition had not yet become exclusive to the museum, but were still somehow in circulation as these machinegun shells that could be bought for the price of a postcard. You half expected an old resistance fighter to enter with a gun, place it in a show case, and perhaps paint this a better colour in the process. One had the feeling of being in a place with live roots, although, actually, I think it was the local tourist board that payed to keep the place open at all.

The new (1988) "Memorial pour la Paix" in Caen proved a strange contrast. Inside the white concrete structure of the Memorial you felt as if 50 years had passed in a flash. You were now in the huge space of an airport where ingeniously constructed exhibition cases and mock-ups stretched as far as the eye could see. At the back was an excellent café. 
120 Computer screens and film projectors showed grainy black-white film footage from the fighting in 1944, or old people recollecting. You were seing here a distant past.

Whereas the bunker exhibition in Calais seemed to be the kind of museum people make themselves to keep memorable events alive, Caen on the other hand was calling up a time already beyond living memory. And in doing so, the Memorial had another purpose than merely to document Normandy's fate during WW II. It also provided the visitors with a ready-made eyepiece through which to view the past. The "Memorial pour la Paix" officially subscribed to the ideals of The United Nations including, not least, the human rights.

It should be said that the Memorial was by far the more rewarding museum to visit. You could spend days there. Great pains had been taken to provide and present interesting objects, information in all forms was at your fingertips, the staff was helpful. And unless you were against human rights, visiting the Memorial you should feel to have carried out a sort of pilgrimage for peace and understanding.

But I still liked the bunker in Calais better.

\section{Post-Modern Criticism}

Writers in current museology would probably find that one ought to feel otherwise. Mainstream thought now holds that a $\mathrm{Ca}$ lais-type of museum is not only outdated in technical terms but even more so ideologically speaking. Many, if not all, of these "1. generation museums" can be condemned for being shaped by nationalism, imperialism, euro-centrism, blind evolutionarism, or the like.
This may be so. But, interestingly, these judgements are most often based on ideological analysis of the texts in the exhibition, the catalogue, or official statements-of-intent. Or analysis of the political, social and economic set-up behind the museum. Since very few museums actually state lies in their exhibitions, the postmodern critics focus their criticism on what is left out, or more virtuously: what is "suppressed". But language and power structure alone can hardly describe a medium which, at the core, consists of authentic three-dimensional objects placed in a space. There may be all sorts of intent (some of it unconscious) behind a given exhibition. But an important part of its effect is, what you, the visitor, actually feel and experience there. And this is what much ideological criticism, being preoccupied with the lacks, fails to explain or even note.

What then if you could show a typology of museums by viewing them from the bottomup, or, rather, from-the-entrance-in?

\section{Generations of Museums}

Trying to do this I shall return once more to Calais and Caen. If the bunker in Calais was "1. generation" then the Memorial in Caen might be called "3. generation", a grandchild rather than a child. Somewhere in between you might perhaps put the sensible and didactic type of museum - the ones so commonly shaped in the 1970 'ies - to fill out the role as an intermediary stage, a " 2 . generation".

Using this distinction as a frame for analysis, you might perhaps find that you - too have experienced some of the following differences when visiting museums: 
Type:

Arrangement

Light

Catalogue

Visible staff

Colours

Sound

Smell

Texts (form)

Texts (content)

Walking against

the direction?

Security

Fee

\section{Setting of objects Object next to kind \\ Aims of arrangement Total representation, "everything important" \\ Perspective \\ Touch objects? \\ Rights of group \\ Some, some not \\ Sanctity of objects}

Role of objects

School of literature

Way of collecting

Registration

Magazines

Initiator

Owner

Background group
Funding
Relation to History
Administration
Conservation

keep the rain out

Proof/documentation

Positivist, traditionalist

Passive (gifts)

Donator and year
of acquisition

Stuffed

Pioneer/pioneer group

Private/Association

Friends

Money for things

Part of history

Wise person (lady)

One-type chemical,

keep the

Compared to travel Your parents' grave

Employees' attitude We are a family

Reaction to criticism Silence (we know, we have enemies)

Reaction to threat

of being shut down Stupefication, determination

Enemy of concept Time

Imprint/function A monument
2. Generation museum

Planned course

Indicative

Points-to-take-home

Uniformed guards

Many, douce/dark

Surround

None, plastic paint

Print

Why (long)

You are told the right direction Guards walk rounds

Reasonable, reduction for schools

Object and text

Selective, "everything

important explained"

Rights of society

Special room

Basis for the texts

Information

Revisionist

Active collecting according to plan

Original function

Ordered, climate-control

Reformer

Public, Large corporation

Association of friends

Money for staff

Represents history

Skilled ladies, male boss

Skilled, planned, growing

Functions of words,

the clause

charter-trip

We are professionals

Refutation in report

Demand for job security

Obligations

Official opinion
3. Generation museum

Scenographic

Aesthetic

Essays and advertisements

Actors, focus-group solicitors

Few, stark

Videos

Coffee

IT-screen

Choose

No particular direction

High-tec

What the market will bear

Surprise

Details of episodes

and individuals

Rights of individual

Special room for children

Holy (until exhibition

is changed)

Fascination

Post-modern, de-constructive

Bought/hired/loaned

History of reception

Whole collection is on show Conceptualist, entrepreneur

Public Agency/Self-sustaining business

Sponsors

Money for events/projects

What it means to the curator

Equal and pursuing a carreer

Selected objects, TV-event

when it happens

The text: what could

it mean?

Survival tour with correct

implements

We're great

Media management

Develop new concept

Expectations

Current trend 
122 Now, viewing the properties of the generations from the top down it should be possible to get a little closer to the qualities of each one.

\section{The i. Generation Museum}

The 1. generation museum might have "personal" as its keyword. It is founded to celebrate a victory won or wealth acquired, by a person or by a class. Examples from Denmark might be the Rosenborg Castle (the Oldenborg kings from 17th to 19th Century), The Open Air Museum (Following the political breakthrough around 1900 of the farming class), The Museum of Danish Resistance 1940-1945 (Summer of 1945) or the Workers' Museum (Founded by the Danish Trade Union Movement in 1971), all in or near Copenhagen.

The outlook of the 1 . generation museum is of its nature partisan. It is tied to its founders almost to the point of being a part of them.

Most 1. generation museums eventually change into a 2. generation form (see below). But if the external and internal demands for modernization can be suppressed one of three things may happen. The museum may simply be closed down for lack of relevance, but this almost never happens. If it can refine its best "1. generation characteristics" (for instance the rarity of its objects) it may go on as before eventually reaching the position of being Heritage. This has happened to the Rosenborg Castle, which e.g. exhibits the Danish crown jewels. No one now seriously expects Rosenborg to mention the suppressed copyholders who payed for them.

The third (but very rare) possible role for an un-reformed 1 . generation museum is that of a Cult-museum, that is a museum so out- dated that it still faithfully reflects a now defunct culture or mind-set. Until its removal in 1967 the old Copenhagen Zoological Museum was such a museum. Crammed in everywhere you might find rows upon rows of specimens in glasses with alcohol, brought home from foreign countries at the cost of lives and meticulously marked with unreadable labels. Some still regret that it is no longer there.

But the Cult-status is not something that can be reached by design. It has to sincerely represent a genuine but now failed effort of understanding the world.

\section{The 2. Generation Museum}

The 2. generation museum may have "education" as its catch-phrase. They are developed from - and usually in opposition to - a 1 . generation form. Every 2. generation museum has somewhere in its history a fierce battle between the founders and the reformers, won by the latter, who (guiltily) take pleasure in finally doing away with the outdated or outrightly false statements in the 1 . generation exhibition. But they also represent the attractive belief that History can be learned, Man can be educated and that society can profit from it. They are therefore also the type of museum that most openly state a purpose. This, however, does not necessarily prevent them from being as one-eyed, or propagandistic as the 1. generation museums. The museums in the old East-Bloc usually had the properties listed above under 2 . generation.

In any case the assumption that people visit museums in order to be taught is probably wrong. Professionals and students may do, but the general public in a free society has a whole range of other reasons than education when 
they enter museums, curiosity perhaps being the most important one.

The 2. generation museum is an unstable type. Whereas the 1 . generation museum is basically satisfied with itself as it is, and is ready to live on a stone, the 2 . generation museum has a built-in propensity to expand. There is no real limit to the amount of objects it will collect or the costs it will claim to conserve them. The exhibition, which seldom recognizes the emotional needs of the guests, tends to be stale, because it has much fewer objects than a 1. generation museum. It uses them merely as a means that could ideally be replaced simply by a text. This disregard for the powers of the object will lead to the loss of visitors, a loss that can seldom be made up for by the forcibly enrolled school-pupils. It is probably no coincidence that the 2 . generation museum is usually to be found in states that are, or aspire to be welfare states. And like the welfare state the 2 . generation museum is threatened and in the end perhaps felled by the pressures on its economy. The state or large corporation that supports it demands a better return on its money in terms of visitors, exhibitions, arrangements and media exposure. It must change into a 3. generation museum.

\section{The 3. Generation Museum}

The 3. generation museum is post-modern. The properties, I have listed above are, of course, something of a caricature. In reality a 3 . generation museum might (like the Memorial in Caen) incorporate many of the qualities of the 2. generation museum. Actually there may not exist a "pure" 3. generation museum anywhere yet. But on the other hand one can see it developing in our present museums.
In theory a 3. generation museum may have 123 no roots in a former museum. But in that case, as a wholly new venture, it might prefer to take the shape of a "Theme Park", which is hardly a museum at all. Usually a 3 . generation museum will be a reformed 2. generation museum. It will have learned an important lesson from the failed parent: museums are about objects, not texts. The 3 . generation museum will take great pains to procure just the right objects. There are several reasons for this. The first is that modern media in its rapid expansion has failed to expand its credibility as well. Perhaps even the reverse has happened. News, History, the Internet all exist on just a screen, where they compete for attention.

Against this background objects of proven authenticity have now begun to carry more weight as elements in the communication of the past. A simple, functional cause for this is that the museum medium with its spatially placed objects can be accessed in much the same way you use a computer: from any side and instantaneously. You can look at an object, pass it by or return to it, the choice is "digital". In this sense the museum is different from the book, the film, the song or the tale who are all "analog" and must be digested from one end to the other. But the museum combines this zap-quality with a tactility, a feeling of direct access to the past, that the electronic screen simply lacks.

There is, however, another reason for the new role of the authentic object. Postmodernism sometimes claims that the means of communication - the "text" - itself constructs the reality it wants to convey. All the phenomena around us do not really exist until they have been formulated as a text ("text" being also other media than the written one). But 
124 any statement, any text, it is argued, is also always a statement from some position, a special interest, and thus a text can always be attacked - in fact: must be attacked - for its hidden agenda and the things it leaves unsaid. Taken in its literal meaning this puts the museum text writer in a difficult position. It seems she is suddenly burdened with actually creating the past, and, not being God, she prefers to step back and "let the object speak for itself". Therefore some museum exhibitions of the 90s have this anemic, almost barren look, where the curator seems to have simply vanished, and where it has been left to the architect or some invited artist to create a meaning. But this means also that the lasting impression of the museum visitor may end up being the fire-extinguisher on the wall because it had both an understandable purpose and an understandable text.

The 3. generation museum, being a business, is more dependent upon its visitors than the older forms. If the public in this last decade has been searching for fixed values to believe in, the 3 . generation museum must try to answer the need. It does so partly by the cult around its objects, partly by infusing its exhibition and arrangement with a moralistic angle. Anything that smacks of nationalism, racism, sexism etc. is avoided if not outright condemned. Equality and human rights are stressed. If asked, the 3. generation museum can also show that it has internal programs for equal rights, hiring of minorities and perhaps a policy dealing with the problems of the old or the drunk in its staff.

But this platform has a serious weakness. If the attitudes of the public and the economic climate changes, the 3 . generation museum must go along. It is for instance unlikely that nationalism will return in its old form.
But a museum that now promotes international values over national ones, may one day find itself forced to cater instead to regionalism, because its customers have begun to react in this way against "globalization". And so forth.

\section{WHAT IS WRONG WITH}

\section{the 3. Generation Museum?}

If at least some of what has been said above is correct, then I can also partly answer the question that puzzled me 10 years ago i Normandy.

Spending time in a 3. generation museum is not challenging, it is comfortable. But at the same time you are not quite certain that you are really in a museum. Much of what you see is the same as in the Mall you just left outside. The videos, the café, the museum shop, the service or the string-quartet. Even the objects - although coming from very interesting places - are in a sense matched by the Rolex'es and Ferraris in the Mall and protected by the same kind of security glass.

Why is it that you want to escape from all this and dive down in some old 1. generation museum in stead? Why are biased and outdated museums emotionally superior to the ones that belong to your own time and seems to reflect your life-style and values?

In the first place a good deal of our values, especially the ones that are promoted from above, are always partly false.

The central modern value is the right of the individual, and - with yesterday's heroes and ideologies gone - postmodernism has tended use the plight of the victim as the most telling contrast. The victim has become the protagonist in much historical research and international reporting. But after the fall of 
the Iron Curtain, an important component in human rights has disappeared from view: the fact that rights have not historically been bestowed from above. They have been fought for. And battles, being social and collective enterprises, demand discipline and subordination of the participants, or in a word: sacrifice. Official modern culture no longer seems to be aware of how human rights came to be a value at all. Therefore the museum of the future might be one that combines vague universalist ideals with a deconstruction of the past, and an added opportunity to be a consumer while taking this in.

The point is: would you visit such a museum yourself?

\section{How SHOULd A MUSEUM FUNCTION?}

To the modern museum an escape into tribalism or nostalgia is not desirable or even possible. But the new combination of aestheticism, moralism and the market is hardly more attractive. Perhaps as a beginning something is to be learnt from two of the qualities of the 1 . generation museum.

Here the object basically is a trophy from some great quest of which it is both a result and a proof. Later generations may prefer to use objects to inform the visitors or to fascinate them. But these functions, I suggest, are derived from the original use and cannot stand alone. What good is disinterested collection of information or uninformed fascination? And how could the museum media either inform or fascinate, if there were no real objects?

The authentic object should be respected for its infinite possibilities as an actual part of the past. This sets it apart from the model or the replica. Most people would instinctively 125 reject an exhibition consisting only of models or replicas, or wouldn't go there more than once.

\section{WHY?}

The model may be beautifully made up, exciting, and instructive. Being three-dimensional it is also tactile and can play the part of an object as opposed to the pictures got up on the electronic screen. The model contains a maximum of information - but as a material relic it only points back to the workshop of the model-wright, his dexterity, the types of glue he used, and the knowledge of the mind that planned the model. But then knowledge is important? Why not fill the museums with models?

The model is explanatory and in a wider sense the illustration of a world-view - but in it you can only find what the maker ("the teacher") put there. It constantly empties itself of the information it contains, but has little more to offer. Its limits are clear. And the same goes for the replica. It can never contain more than its maker at a given time saw, understood and was able to reproduce in his copy.

The model is authoritarian. Spritually you are standing down there, somehow looking up at the model and its maker.

But is the authentic object then in-finite and anti-authoritarian? I think so. As any museum-person knows, an object may always turn out to be something different from what we thought it was. Or circumstances may force us to interpret it in new ways. Or it may reveal information that no one "put there", but that we are happy to have suddenly discovered. So, as opposed to the model or the 
126 replica, the authentic object can itself grow in the process of giving off information. This means that we can never be entirely sure about the texts we pin to our objects. They may one day blow up in our faces. And this is what the public senses. Spritually the curators must accept to stand shoulder-to-shoulder with the public in front of the authentic object. Because in the end you never know the final interpretation of the past that it is a manifest part of.

The object, therefore, is potentially subversive.

And this connects to a second 1.-generation-quality. That of attitude. The founders of the 1 . generation museum will of course feel certain that their explanations and use of their objects are self-evidently right.

But basically the 1 . generation museum is a place where strangers from the past want to show you something important. To them. The purpose of the whole institution is to convince you of their importance and right to a place in the world. They are, as it were, showing you their wounds as well as their achievements. But in doing this, they treat you as an equal, because, after all, this is the only way of genuine persuasion.

And this makes you feel good.

Thus the qualities of our museum-grandfathers are that they chose to document their own past by unashamedly putting objects from it on view. And that in doing so they created a medium that can - potentially transcend some of the barriers that divide us from them and, perhaps, us from each other.

\section{Notes}

- A previous version of the text has been published in Danish: Esben Kjeldbæk: Ting fra besættelsen, s. 359-
93, in: Dethlefsen og Lundbak (red.): Fra mellemkrigstid til efterkrigstid. (1998)

1. In the following the Memorial in Caen is no longer the concrete model of "the 3. generation museum".

2. The director of Rosenborg Castle once said that of all the Copenhagen museums he felt the closest likeness to the Workers' Museum. And quite right: both basically communicate by showing authentic interiors of dwellings. Time will show, if the Workers' Museum can keep going as long as Rosenborg.

3. But if the economy calls for less spending, staff will get the axe, no questions asked. Conversely, the 1 . generation museum might fire persons who do not support its concept, but will try to keep on staff, that are endangered by mere economy.

Esben Kjaldbak is Curator of The Museum of Danish Resistance 1940-1945 (Fribedsmuseet).

Adr: Churchillparken, DK-1263 Koebenhavn K.

Fax: +45-33140314.

E-mail: esben.kjeldbak@natmus.dk 